This is a self-archived version of an original article. This version may differ from the original in pagination and typographic details.

Author(s): Maunula, Minna

Title: Expertise as Capital - Experienced and Estimated by Doctoral Students

Year: 2020

Version: Accepted version (Final draft)

Copyright: @ 2020 IATED

Rights: In Copyright

Rights url: http://rightsstatements.org/page//nC/1.0/?language=en

Please cite the original version:

Maunula, M. (2020). Expertise as Capital - Experienced and Estimated by Doctoral Students. In L. G. Chova, A. L. Martínez, \& I. C. Torres (Eds.), INTED 2020 : 14th annual International Technology, Education and Development Conference, Proceedings (pp. 523-528). IATED Academy. INTED Proceedings, 2020. https://doi.org/10.21125/inted.2020.0211 


\title{
EXPERTISE AS CAPITAL - EXPERIENCED AND ESTIMATED BY DOCTORAL STUDENTS
}

\author{
Maunula Minna \\ University of Jyvaskyla (FINLAND)
}

\begin{abstract}
There is a great and constantly renewed expectation of doctoral education, the highest level of specialist training, and of doctors globally. The Finnish education and university field is also repositioned to create greater opportunities for continuous and sustainable learning. The goal for a long time has been that doctoral education should increasingly produce a more sophisticated teams of experts with expert knowledge and skills that meet the demands of digital and global, as well as forward-looking innovative visions. On the other hand, at the same time, doctors face uncertainty about the nature of their expertise and even the challenges of employment in their working life. However, the fields of expertise of the experts are becoming more diverse and slowly integrating but are still partly unstructured. This paper focuses on doctoral students' own experiences and assessments of their expertise and its value as capital.
\end{abstract}

Keywords: expertise, doctoral studies

\section{INTRODUCTION}

In Europe, higher education has been integrated through the Bologna Process and the Lisbon Strategy [1]. International control over the measurable best is underway. Systematic and rapid changes that are hard to predict are reflected in both universities and other expert working life contexts and fields. In the shadows of media-driven megatrends, there is an everyday level of dialogue where individuals are constantly seeking the best possible balance and fluency. In public discussions, the individual and the individual's experience of building expertise in the context of doctoral studies, as well as the possibilities to utilize expertise, often fall to the margin. Attempting to create understanding of the systemic process between different components and participants is important.

For the purposes of this study, expertise refers to the broad body of knowledge, skills and knowledge that are embedded in doctoral studies. Many researchers [2; 3; 4], define expertise as an operating model that produces a consistently high level of performance. Expertise is a dynamic attitude that constantly strives to perform better in more demanding tasks. It is characteristic for expert that elements of knowledge are seamlessly integrated into existing concepts of information and strengthen the whole [5]. Experts use flexibly both formal and informal information, which includes an experiential, intuitive, and self-regulatory dimension [6].

According to the current and widely accepted view, expertise consists of four key dimensions: theoretical, conceptual and factual knowledge, practical and experiential knowledge, self-regulatory knowledge and socio-cultural knowledge $[7 ; 8 ; 2 ; 9]$ Theoretical information can be presented in the form of text or speech. Practical information is created through practical action and experience. Practical knowledge contains a skill element, but it also essentially involves knowledge. Practical information is often tacit knowledge and is often related to the nature of different processes, but it can also be explicated by reflection as needed. Reflection generates self-regulatory information, that is, metacognitive and reflective knowledge of one's own working and working methods, thinking and learning. As reflective reflection expands beyond self, expertise attaches to broader contexts, such as one's own community. Socio-cultural expertise includes social and cultural information, unspoken rules of conduct, and can only be accessed through participation in the practical activities of a particular community. The transition from individuals' expertise to community expertise is accelerating [10]. It is essential for the expert's work that the different components of knowledge do not separate from each other, but they merge into an intuitive and meaningful whole. Collective inventiveness is typical of time and requires continuous learning, education and community action [3].

Expertise is multidimensional and possessively developing, and comprehensive meta-levelling of expertise is one of the essential goals of doctoral studies. Expertise basically requires a high level of training, but it is only the starting point of the process. Changes and new requirements will be reflected 
in the expertise and its constant repetition, while individual foresight should be made from the perspective of our own expertise [11]. In doctoral studies, individual expertise development processes are launched, while doctoral students are guided by the practices of the academic community, their own individual life situations and, on the other hand, a changing society and working life. Expertise increasingly emphasizes both individual and communal, even networked perspectives. Continuous learning, the renewal of working life and the value of expertise are things that occur in the analyses of changing working life - and the same is the core of doctoral expertise, regardless of the field. Doctoral studies and processes of expertise are at the crossroads of many changes and pressures, providing many interesting aspects of review.

Not even PhD students themselves structure the components and structure of their own expertise, its various components and potential contexts of use [12]. Increasingly, doctors are moving beyond the academic field. There is a growing need for scientific knowledge to be exploited. These result in the dissolution of fields, academic and other boundaries. Doctoral expertise is also hybrid, that is, broad and applicable. Interactive development of communities and individuals is emphasized in creating new approaches and innovative information communities. Networked expertise can be seen as an interaction between individuals, communities and networks. [3.] The characteristics of the development of expertise are closely related to global change, they have in common adaptability and formability. Systemic change requires a rapid and targeted response at the fringes of different areas of expertise. At the same time, there is a profound specialization and crossing traditional boundaries. Further, the key element of expertise is to produce change, not just react to change. [3;13.]

Bourdieu's [14;15] theory of capital and fields can also be viewed in the context of doctoral education and its expertise. According to Bourdieu, individuals seek access to different fields and generate different capital. The success of an individual in various fields is directly related to the composition and amount of capital he has acquired. Bourdieu's field means a socially constructed space in which, depending on one's position, one struggles to achieve or preserve certain things. The various fields seek to raise and consolidate capital that can be utilized in different fields.

Bourdieu divides capital into three basic categories: economic, cultural and social capital, which are universal and valuable in all fields. Bourdieu's [14] theory of reproduction of capital is also applicable to examining the construction of expertise experienced by doctoral students. Expertise built on different dimensions in doctoral studies can be seen in the academic field as capital, primarily cultural and educational, but also as other capital, such as social capital through networking and building.

With the constant development of change, the academic field is also changing, and capital factors are valued there. Symbolically effective capital is a concept developed later [15], which describes a continuous and typical change in our time. Any form of capital or individual can have significant value. This could be a new innovative scientific achievement or a recognized scientific recognition. Publicity and profiling as a well-known science-media personality can also be such a symbolically effective capital. Educational capital is, according to Bourdieu, a capital which helps to accumulate different capital and contributes to the uneven distribution of capital and is therefore of particular interest.

\section{METHODOLOGY}

The paper is based on qualitative research analysis, and the core interest is: what kind of expertise in doctoral studies is built up according to the doctoral students themselves, whether can expertise be defined and estimated as useful capital in different fields.

Research Question: What kind of capital expertise is in different fields experienced and evaluated by doctoral students?

The research material consists of a narrative theme interviews of nine female doctoral students or a fresh doctorate with family. The investigated were selected discretionary, they are the same persons whose lifespans I did study seven years earlier in my dissertation.

The aim of the study is to deepen understanding by looking at individual experience. The focus of the analysis is on the experiences of the participants in building their expertise in the doctoral study process. The study explores the individual's experience of expertise as capital in various fields. The doctoral degree and the extensive expertise generated by the process can be seen in the Bourdieulian view as capital that is utilized in various fields. In this study, the doctoral capital is expertise and the fields of action are the academic and non-academic contexts, ie the university and the non-academic labour market. 


\section{RESULTS}

\subsection{Doctoral student's experience of their expertise}

In this study, the theoretical dimension of expertise was taken more strongly and for granted than other areas of expertise. The respondents described their theoretical training capital as strong in their own research topic, in their own discipline and more broadly in the academic field. Theoretical and research expertise was the strongest emphasis on expertise. Theoretical expertise constituted the educational capital that others sought in the academic field [14]. This resulted in competition and comparison of the value of equity with other field competitors, especially those involved in doctoral education. The competition took place both against and with doctoral students.

Many of the main types of capital overlapped with competition in the academic field: cultural and educational capital was pursued through advancement in the field of science and doctoral studies, economic capital was linked to employment, that is, whether gaining academic chores or succeeding in project competition. Social capital was related to relationships with close doctoral students and to networking in the discipline, generally in the academic field, as well as private, supportive networks.

In the academic field, practical expertise was strongly capitalized as cultural and educational [14]. It overlapped in the narratives of the subjects into a union of know-how and skill. Field competitions were generally recognized as valuable theoretical expertise, but the combination of practical expertise $[16 ; 17]$ created opportunities to differentiate themselves from competitors in the same field [14].

"I do not see it as a diploma, not just a piece of paper or a diploma, but a job. I like that dimension a lot in this job."

The researchers identified their practical expertise in the academic field as the ability to conduct their own research or to promote research activities as part of the research team, and the process of developing these skills, reinforcing social capital.

"I learned to be very independent and self-guided when there was not as much guidance as I thought ahead. But in retrospect, it has been good, allowed to make decisions and direct the direction of the work. It is good and bad that we have had to apply for funding all the time. It took time, but on the other hand it has also learned."

Also, individualized and discipline-specific research methodological expertise was perceived as a strength, highlighted as a special practical aspect of the expert and as educational, partly economic and social capital. This was valuable capital especially when similar method skills were not available, within the same team, unit, university or country. From an individual perspective, rare and highly specialized expertise and its practical relevance to the academic scientific community were capital and a competitive advantage.

In addition to the actual research dimension, the researchers said that their work included tasks that apply expertise and strengthen cultural capital. These included various practical development projects, popular events and publications, as well as new scientific innovations that involved in-house expert input. Participation in concrete tasks at the fringes of theoretical expertise created added value and added social and cultural capital, such as networks, increased visibility or strengthened language and project skills. Experts from different disciplines or maritime experts in their fields also learned in a variety of ways, thus gaining valuable social and cultural capital in the academic field, while enabling the growth of one's future potential in the form of a symbolically effective idea of capital.

Some of the participants in the study said that teaching as an integral part of their work in the academic field. Pedagogical competence and content expertise produced substantial cultural, social and, to some extent, economic capital in the academic field. However, teaching assignments were not perceived as providing highly valued expert capital in the academic field. However, pedagogical skills strengthened the position in the academic field and provided an opportunity to engage with the academic community.

The researched doctoral students discuss the significance of internationalization and networking more broadly. According to them, international networking and the cultural and social capital that they accumulated contained many dimensions of expertise.

The value of expertise in the academic field as capital was special expertise in research content, teaching, research methodology. Using all these expertise skills dialogically, you were awarded a place on the academic field for your expertise, or permission to compete in the academic field. 
Expertise, considered as capital, required the field and context to make capital worthwhile and productive.

The experience of expertise and different capital revealed both strengths and weaknesses. Research and working at the University are of the nature of continuous learning and exploring new opportunities. Continuously Complementing expertise was deeply embedded in one's own academic identity and in one's own way of dealing with things. Weaknesses in one's own expertise were not negative things, but natural and positively challenging things, raising capital.

At the same time, a certain relativist attitude was emphasized, no one can ever manage all knowledge or educational capital, even within their own narrow field of expertise. The subjects reported their awareness of the logic behind the action in the academic field and the valuable expert capital with the increased involvement. They had a built-in understanding of the nature, values and ways of working in the academic community - they had adopted a certain field of logic. Working in the academic field was mainly related to the dimensions of cultural, educational and social capital, which were closely linked to the practical, academic life. Economic capital was also present, but in the role of an enabler, not at the core of operations.

\subsection{Expertise as capital in the fields}

The dimensions of doctoral student expertise relate to Bourdieu's capital and fields. In a closer analysis of the doctoral capital expertise, financial capital seems to be related to the doctor's ability to find employment in a variety of fields, whether academic or non-academic. In this study and in the Finnish context, the field of academic employment was still to be pursued as a priority in the interpretations of doctoral students, but internationally the labour market fields outside the academic field appear to be more attractive than the academic one.

Cultural capital is an educational capital that is clearly linked to the doctoral degree and builds a prestigious position. Of Bourdieu's types of capital, social would appear to be the most growing, potential, and particularly relevant in the light of expertise. To sum up, an expert's capital is the ability to conduct high-quality research with other experts and thus expose one's own expertise to others' appraisal and self-evaluation. Social capital is also reflected in economic capital, for example, through networks, the doctor can promote his employment.

A subset of cultural capital, educational capital can be interpreted as increasing with a doctorate, which also increases opportunities for other capital. Expertise and educational capital seem to be controversial at the moment, both nationally and internationally. However, the historical perspective shows that cultural capital is valuable for general social development and maintains the idea of civilization.

The value and logic of the expert's capital have since changed in Bourdieu's time and continue to fluctuate in the processes of change [14]. Capitalization, that is, direct or indirect power of money, seems to have gained an inferior position in most fields. On the other hand, all forms of capital are networked and interact in different contexts and fields. Because of the complexity of the situations, the hidden mechanisms of action and the changing nature of the situations, it can be interpreted that all capital is potential in the future, symbolically effective [14], and thus valuable.

The overall challenge for doctoral education, expertise, and acquired capital is to break the everyday notion of a doctor's narrow and difficult-to-use expertise. According to the data of this study, the accumulated expertise in doctoral studies is capital, knowledge and skill in various fields. The dimensions of expertise will not develop if they cannot be processed in an authentic field. Indeed, it can be interpreted that the diverse fields of the past and the present will continue to provide diverse fields in the future.

\section{CONCLUSIONS}

Expertise is a multidimensional construct structured in different contexts, including the dimensions of doctoral expertise: theoretical, practical, sociocultural and self-regulated, giving the process phase and overall contexts unique nuances. Theoretical and practical expertise can be used to raise financial capital if one enters a field, either the primary academic field desired in this study, or other fields, the 
labour market. The fields also require socio-cultural and self-regulated processing in the process of expertise, which can be seen in the Bourdieu sense as social capital. By participating in different fields, the expert accumulates cultural capital, status and symbols. The doctor's habitus as an expert, field and academic is a complex entanglement. Without participation in the fields, that is, the labour market, the dimensions of expertise and potential capital will not become available and grow. Participation and ongoing processes - from all angles - are essential. As a result, the development process as an expert continues and as capital moves around, capital accumulates in many ways. Versatility is essential because changes can fluctuate in the value of individual capital.

According to the study, there is still an unrecognized and differentiated expertise in doctoral studies that would be more readily available in different fields as capital if the construction process was more conscious and known. The expertise of a doctor is refined at the intersections of different contexts and at the intersection of fields. In doctoral studies, awakening a meta-level awareness of the dimensions and processes of expertise and engaging in dialogues across fields will benefit the doctor in recognizing and developing the dimensions of his or her expertise. Doctoral students sought a versatile pool of expert capital that could be leveraged in a hybrid manner across fields. I welcome this, as the dimensions of expertise are actively mobilized and further processed. In this way, expertise accumulates as capital and also as symbolically effective capital.

\section{REFERENCES}

[1] Bitusikova, A. "New challenges in doctoral education in Europe". In D. Boud \& A. Lee (eds.) Changing practices of doctoral education. London: Routledge, pp. 200-210. 2009.

[2] Ericsson, K.A., Charness, P., Feltovich, P. \& Hoffmann, R. (eds.) The Cambrigde handbook of expertise an expert performance. New York: Cambridge University Press. 2006.

[3] Hakkarainen, K., Palonen, T, Paavola, S. \& Lehtinen, E. Communities of networked expertise: Educational and professional perspectives. Amsterdam: Elsevier. 2004.

[4] Ericsson, K.A. "The influence of experience and deliberate practice on the development of superior expert performance". In K.A. Ericsson, N. Charness, P. Feltovich \& R. Hoffman (eds.) The Cambrigde handbook of expertise an expert performance. New York: Cambridge University Press, pp. 683-704. 2006.

[5] Chi, M., Glaser, R. \& Farr, M. (eds.) The nature of expertise. Hillsdale, NJ: Lawrence Erlbaum. 1988.

[6] Bereiter, C. \& Scardamalia, M. Surpassing ourselves: An inquiry onto the nature and implications of expertise. Chicago: Open Court. 1993.

[7] Bereiter, C. Education and mind in the knowledge age. Mahwah: Lawrence Erlbaum Associates. 2002.

[8] Erault, M. "Informal learning in the workplace". Studies in Continuing Education, 26 (2), pp. 247273. 2004.

[9] Palonen, T., Boshuizen, P. A. \& Lehtinen, E. "How Expertise Is Created in Emerging Professional Fields". In: Halttunen T., Koivisto M., Billett S. (eds.) Promoting, Assessing, Recognizing and Certifying Lifelong Learning. Lifelong Learning Book Series, vol 20. Springer, Dordrecht. Pp. 131-149. 2014.

[10] Tynjälä, P. "Perspectives into learning at the workplace". Educational Research Review 3 (2), pp. 130-154. 2008. https://doi.org/10.1016/j.edurev.2007.12.001

[11] Beck, U. \& Beck-Gernsheim, E. Individualization. London: SAGE. 2012.

[12] Golde, C. \& Dore, T. At cross purposes: what the experiences of today's doctoral students reveal about doctoral education. 2001. https://files.eric.ed.gov/fulltext/ED450628.pdf

[13] Ericsson, K.A. \& Pool, R. Secrets from the New Science of Expertise. Boston: Houghton Milffin Harcourt. 2016.

[14] Bourdieu, P. "The forms of capital". In J. Richardson (eds.) Handbook of theory and research for the sociology of education. New York: Greenwood Press, pp. 241-258. 1986. 
[15] Bourdieu, P. \& Passeron, J.-C. Reproduction in Education, society and Culture. London: SAGE. 1998.

[16] Thune, T. "Doctoral students on the university-industry interface: a review of the literature". Higher education, vol. 58, pp. 637-651. 2009.

[17] Tymon, A. "The student perspective on employability". Studies in Higher Education 38 (3), pp. 841-586. 2013. 